Article

\title{
Chemical Profile, Antibacterial Activity and Antibiotic-Modulating Effect of the Hexanic Zea Mays L. Silk Extract (Poaceae)
}

\author{
Ana Beatriz Linard de Carvalho ${ }^{1}$, Cleciana Alves Cruz ${ }^{2}$, Cicero Lucas Almeida de Freitas ${ }^{3}$, \\ José Junior dos Santos Aguiar 1,3, Paula Leticia Wendy de Souza Nunes ${ }^{1}$, \\ Valéria Maria da Silva Lima ${ }^{1}$, Edinardo Fagner Ferreira Matias ${ }^{3} \mathbb{D}$, Débora Feitosa Muniz ${ }^{4}$ and \\ Henrique Douglas Melo Coutinho ${ }^{4, * \mathbb{D}}$ \\ 1 Department of Nursing, Universitary Center Dr. Leão Sampaio, Juazeiro do Norte 63040-005, Brazil; \\ bia-linard@hotmail.com (A.B.L.d.C.); josejunior@leaosampaio.edu.br (J.J.d.S.A.); \\ paulaleticiawendy@hotmail.com (P.L.W.d.S.N.); valeriasilvalima2016@outlook.com (V.M.d.S.L.) \\ 2 Department of Nursing, Vale do Salgado College, Icó 63430-000, Brazil; clecianacruz@fvs.edu.br \\ 3 Department of Biomedicine, Universitary Center Dr. Leão Sampaio, Juazeiro do Norte 63040-005, Brazil; \\ cicerolucasalmeida@yahoo.com.br (C.L.A.d.F.); effm_biologia@hotmail.com (E.F.F.M.) \\ 4 Department of Biological Chemistry, Regional University of Cariri, Crato 63105-000, Brazil; \\ deehmuniz78@gmail.com \\ * Correspondence: hdmcoutinho@gmail.com; Tel.: +55(88)31021212; Fax: +55(88)31021291
}

Received: 3 February 2019; Accepted: 9 March 2019; Published: 12 March 2019

\begin{abstract}
The present study aimed to determine the chemical profile and to evaluate the antibacterial activity and antibiotic-modulating action of the hexanic Zea mays silk extract in association with aminoglycosides. Standard Escherichia coli ATCC 25922, Staphylococcus aureus ATCC 25923 and Pseudomonas aeruginosa ATCC 27853 strains, as well as multi-resistant Escherichia coli 27, Staphylococcus aureus 35, and Pseudomonas aeruginosa 31 strains, were used in this study. Phytochemical prospection revealed the presence of the following secondary metabolites: tannins, flavones, flavonoids, and xanthones, with the main chemical constituents being identified in plant extracts obtained with apolar organic solvents such as hexane. The extract presented a minimum inhibitory concentration (MIC) $\geq 1024 \mu \mathrm{g} / \mathrm{mL}$ against all the tested strains. The association of the extract with aminoglycoside antibiotics showed significant synergistic effects against Staphylococcus aureus and Pseudomonas aeruginosa, except for amikacin, which was antagonized by the extract against $E$. coli. These results indicate the Zea mays silk presents bioactive compounds with antibiotic-modulating properties. However, further research is required to characterize the effects of isolated compounds and determine their potential for drug development.
\end{abstract}

Keywords: bacterial resistance; hexanic extract; Zea mays L.

\section{Introduction}

Medicinal plants have been widely used for therapeutic purposes throughout generations [1] and for many people constitute an essential patrimony that must be preserved. In fact, the study of plant pharmacological properties has contributed significantly to the treatment of various diseases [2].

The Zea mays L. (POACEAE) species, popularly known as "corn" ("milho" in Portuguese) is widely used in Brazilian folk medicine to treat genitourinary tract diseases. This species is characterized as a monoecious plant which produces fruits and seeds [3,4]. Its stem is erect with an average height of 1.30 to $2.5 \mathrm{~m}$ and the leaves may be light green or dark green in color. Zea mays L. presents masculine flowers (arrows or pennants) at its highest part, where pollen grains are produced, and female flowers 
(spikes) along the stem. Each silk strand is responsible for grain production after fertilization. The silk is an elongated stylet that emerges from the tip of the spike from each female flower [4,5].

Corn silk is used by people from different countries to control blood pressure and treat a series of conditions, such as fever, gout and urinary tract infections, in addition to other bacterial diseases [6,7].

In studies performed with Zea mays silk extract against Staphylococcus aureus, Escherichia coli and Pseudomonas aeruginosas standard and multiresistant strains obtained significant results for the extract's bacterial resistance modulatory activity, when tested alongside aminoglycoside antibiotics [8].

One of the greatest challenges in the treatment of bacterial infections is antibiotic resistance. While most microorganisms die when exposed to therapeutic doses of conventional antibiotics, some microorganisms become resistant to these drugs, in addition to transferring resistance mechanisms to their descendants [9]. Bacterial resistance is particularly important in opportunistic infections, such as those caused by Staphylococcus aureus. In this condition, microorganisms which are part of the normal microbiota can cause infectious diseases in immunosuppressed patients [10].

In this context, the study of natural products as an alternative to bacterial resistance has been obtaining promising results. In fact, medicinal plants present constituents capable of inhibiting or controlling bacterial resistance mechanisms, which can be obtained and tested at low cost [11].

Therefore, the objective of this study was to characterize the phytochemical profile and to evaluate the antibacterial and antibiotic-modulating activities of the hexanic Zea mays L. silk extract against standard and multidrug-resistant Escherichia coli, Staphylococcus aureus and Pseudomonas aeruginosa strains.

\section{Results}

Phytochemical prospection of the hexanic Zea mays silk extract (HEZM) revealed the presence of four important secondary metabolites, including: tannins, flavones, flavonols, and xanthones (Table 1).

Table 1. Phytochemical prospection of the hexanic Zea mays L. extract.

\begin{tabular}{lllllllllllll}
\hline Extract & 1 & 2 & 3 & 4 & 5 & 6 & 7 & 8 & 9 & 10 & 11 & 12 \\
\hline Hezm & - & + & - & - & + & + & + & - & - & - & - & -
\end{tabular}

1-Phenols; 2-Pyrogallic Tannins; 3-Anthocyanins; 4-Anthocyanidinis; 5-Flavones; 6-Flavonols; 7-Xanthones; 8-Chalcones; 9-Aurones; 10-leucoanthocyanidins; 11-Catechins; 12-Alkaloid; (+) Presence; (-) Absence. HEZM-Hexanic Extract of Zea mays L.

The microdilution test was used to determine the minimum inhibitory concentration (MIC) of the HEZM against standard and multiresistant E. coli, S. aureus and P. aeruginosa strains obtaining MIC values $\geq 1024$ for all tested strains. As shown in Table 2, the extract presented MIC values $\geq 1024 \mu \mathrm{g} / \mathrm{mL}$ against all evaluated strains, indicating that at least for these microorganisms, the extract does not present a significant antibacterial effect.

Table 2. The hexanic Zea mays silk extract (HEZM) minimum inhibitory concentration (MIC) against standard and resistant bacterial strains.

\begin{tabular}{cc}
\hline Bacterium & MIC $(\mu \mathrm{g} / \mathrm{mL})$ \\
\hline Escherichia coli ATCC 25922 & $\geq 1024$ \\
Escherichia coli 27 & $\geq 1024$ \\
Staphylococcus aureus ATCC 25923 & $\geq 1024$ \\
Staphylococcus aureus 35 & $\geq 1024$ \\
Pseudomonas aeruginosa 31 & $\geq 1024$ \\
Pseudomonas aeruginosa ATCC 27853 & $\geq 1024$ \\
\hline
\end{tabular}

To investigate the HEZM modulatory effect, a subinhibitory concentration (MIC/8) of this extract was used in combination with the amikacin and gentamicin antibiotics against multiresistant bacterial 
strains (Figure 1). The results showed that the association of the extract with antibiotics significantly decreased the MIC of the antibiotics against Staphylococcus aureus and Pseudomonas aeruginosa strains, indicating the antibiotics had their effects potentiated by the extract. However, the association of the extract with amikacin against Escherichia coli significantly increased the MIC of this antibiotic, indicating the extract antagonized the effect of the drug. Together, these results indicate that although it does not exhibit a significant antibacterial effect, the extract is capable of selectively modulating bacterial resistance against aminoglycosides (Figure 1).

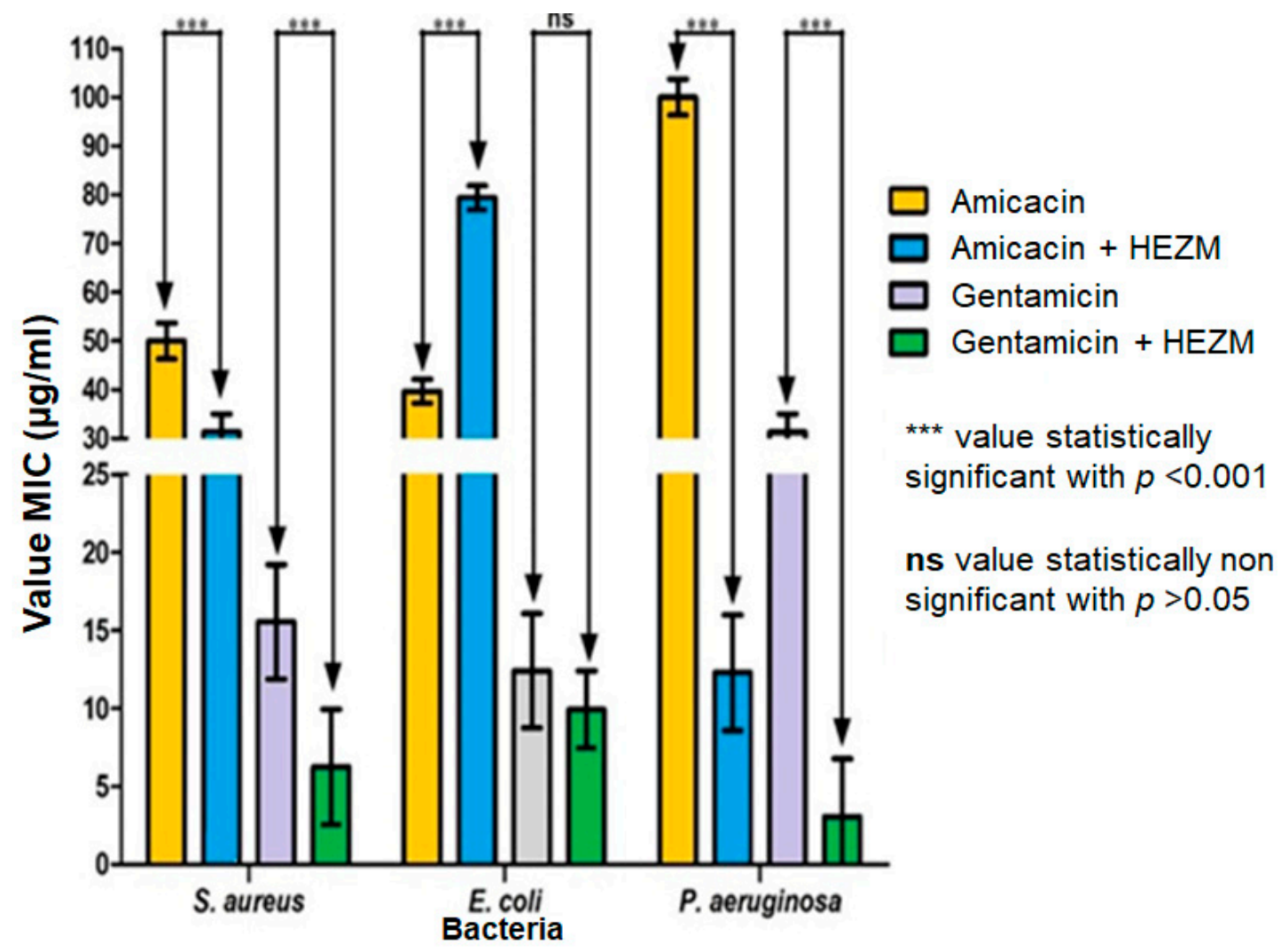

Figure 1. Antibiotic-modulating effect of HEZM against multiresistant bacteria.

\section{Discussion}

According to [12], saponins, calcium, sodium, magnesium, and proteins can also be found in this extract. The flavonoids found in this study belong to an important natural metabolite group common in plant leaves, flowers and roots with effective modulatory potential capable of inhibiting many cellular system enzymes [13]. Xanthones, another metabolite present in the extract, has a family subgroup known as oxygenated xanthones that present excellent antimicrobial action against $S$. aureus strains resistant to norfloxacin, mainly because this type of metabolite presents a hydrophobic property that increases cellular membrane solubility [14]. Tannins found in the present extract have the ability to form protein complexes capable of controlling fungi and bacteria [15,16]. Nishizawa (1990) reports that a number of bacteria are sensitive to tannins at minimum concentrations ( $0.5 \mathrm{~g} / \mathrm{L})$, including Staphylococcus aureus, Streptococcus pneumonia, Bacillus anthracis, and Shigella dysenteriae.

The synergistic effect obtained from the association of the extract with antibiotics in this study may be due to the action of metabolites present in the extract, such as tannins. According to [17], tannins can precipitate proteins and interfere with cellular components in microorganisms, including Staphylococcus aureus, Streptococcus pneumoneae, and Shigella dysenteriae. In addition, the extract contains flavonoids, whose antimicrobial properties have been previously described $[18,19]$. 
The antimicrobial properties present in tannins appear to be associated with the hydrolysis of an ester link in gallic acid, which confers natural defense properties against microbial infections to plant products. Meanwhile, metabolites such as flavonoids, which act at the plasmatic wall of microorganisms, due to their lipophilic affinity, tend to be synthesized in response to infections [20,21].

The association of extracts with aminoglycosides represents a promising therapeutic option for infections caused by resistant bacteria since the potentiation of antibiotic effects can reduce the therapeutic dose and consequently, minimize their side effects [17].

On the other hand, the modulating effect of the extract appears to be different between Gram-positive and Gram-negative microorganisms, given the results with Staphylococcus aureus (Gram-positive) were different from the results with E. coli and P. aeruginosa (Gram-negative). In fact, Gram-negative bacteria present a thin peptidoglycan layer, whereas Gram-positive bacteria present a more complex lipid layer. Thus, these differences in the chemical components of these microorganisms may be the determinant factor in the antibiotic response [19].

These factors may also justify the antagonistic effect observed in the assays with E. coli, since the compounds present in the extract could interfere with the binding of amikacin to bacterial lipid compounds, decreasing the activity of this drug [22]. In addition, the tannins present in the extract could also interfere with the activity of the drug through a chelating effect [22].

\section{Materials and Methods}

\subsection{Botanical Material}

Corn silk samples were collected from a family farm located in a place known as "Sítio palmeiras" in the municipality of Crato-CE, Brazil. The geographic coordinates are Latitude: $7^{\circ} 13^{\prime} 46^{\prime \prime}$ South and Longitude: $39^{\circ} 24^{\prime} 32^{\prime \prime}$ West. A sample specimen was deposited in the "Dárdano de Andrade Lima" Herbarium, at the Regional University of Cariri-URCA under sample number: 13.351.

\subsection{Hexanic Extract and Solution Preparations for Antibacterial Assays}

For the preparation of the hexanic extract, $356 \mathrm{~g}$ of Zea mays silk were crushed and placed in a glass flask containing $1 \mathrm{~L}$ of hexane. The material was kept submerged in the solvent for at least $72 \mathrm{~h}$ and was then transferred to a rotary evaporator in a water bath to remove any organic solvent residue, yielding $12.46 \mathrm{~g}$ of a raw hexane extract, which corresponded to $3.5 \%$ of the total collected and processed silk. This extract was prepared to a concentration of $10 \mathrm{mg} / \mathrm{mL}$, dissolved in dimethyl sulfoxide (DMSO) and diluted with distilled water to a concentration of $1024 \mu \mathrm{g} / \mathrm{mL}$ [23].

\subsection{Extract and Phytochemical Prospection Acquisition}

The hexane extract was obtained using Zea mays silk strands, for which the silk strands were collected, weighed and ground to increase their surface area, followed by deposition in a glass flask containing the organic solvent at a volume sufficient to submerge all the material. This was maintained closed for $72 \mathrm{~h}$. Thereafter, the material was filtered using filter paper to eliminate possible solid residues with the contents later being concentrated in a vacuum rotary condenser (model Q-344B, Quimis, Campinas Brazil) and water bath (model Q-214M2, Quimis, Brazil). Phytochemical prospection was carried out according to the methodology proposed by [24] to investigate the presence of chemical compounds, such as coumarins, quinones, triterpenes, steroids, organic acids, and alkaloids. The tests are based on colorimetric changes or precipitate formation after the addition of specific reagents and $\mathrm{pH}$ variations, which can be visually evaluated.

\subsection{Minimum Inhibitory Concentration (Mic) Determination}

The minimum inhibitory concentration (MIC) of the hexanic Zea mays silk extract (HEZM) was determined through the broth microdilution assay [25-27]. A $100 \mu \mathrm{L}$ volume of the inoculum from each strain was prepared in $10 \%$ BHI broth at a concentration of $10^{5} \mathrm{CFU} / \mathrm{mL}$, placed in 96-well 
microdilution plates and serially diluted 1:2 [28]. The HEZM $(100 \mathrm{~mL})$ was added to the first well and diluted to reach final concentrations ranging from $512 \mu \mathrm{g} / \mathrm{mL}$ to $8 \mu \mathrm{g} / \mathrm{mL}$. The last wells were reserved for the controls using the standard antibiotics amikacin and gentamicin, whose concentrations varied from $2500 \mu \mathrm{g} / \mathrm{mL}$ to $2.4 \mu \mathrm{g} / \mathrm{mL}$. The plates were incubated at $37^{\circ} \mathrm{C}$ for $24 \mathrm{~h}$ and after this period the results were evaluated by using resazurin as a colorimetric indicator of bacterial growth $[29,30]$. The readings were performed using a spectrophotometer and the MIC was defined as the lowest concentration capable of inhibiting bacterial growth [27]. Pilot tests were performed to evaluate the interference of DMSO, where at a concentration lower than $10 \%$ the solvent has no influence on the results. These tests were performed in triplicates using only multiresistant bacterial strains.

\subsection{Aminoglycoside Antibiotic Resistance Modulation Analysis}

To analyze the HEZM effect on bacterial resistance to aminoglycoside antibiotics, the method proposed by [23] was used, where the HEZM was tested at a subinhibitory concentration (MIC/8). In addition to the extract solution, $100 \mu \mathrm{L}$ of the bacterial inoculum solution in $10 \% \mathrm{BHI}$ were added to the wells. Antibiotic solutions were prepared using sterile distilled water at a concentration of $5000 \mu \mathrm{g} / \mathrm{mL}$. Then, $100 \mu \mathrm{L}$ of this solution was added to the first well and serially diluted (1:2) up until the penultimate well to reach concentrations ranging from 2500 to $2.44 \mu \mathrm{g} / \mathrm{mL}$. The last well was reserved for the control [23], where these were expected to grow in the absence of antibiotics, thus validating the tests. The plates were incubated at $37^{\circ} \mathrm{C}$ for $24 \mathrm{~h}$ and readings were performed as described above. These tests were performed in triplicates using only multiresistant bacterial strains (Table 3).

Table 3. Resistance profile of the bacteria used in the tests.

\begin{tabular}{cccc}
\hline Bacterium & N & Collection Site & Resistance Profile \\
\hline Staphylococcus aureus & SA358 & Surgical wound & Oxa, Gen, Tob, Ami, Can, Neo, Para, But, Sis, Net \\
\hline Pseudomonas aeruginosa & P31 & Nose & $\begin{array}{c}\text { Pol, Cpm, Ctz, Ptz, Ami } \\
\text { Imi, Cip, Lev, Mer, }\end{array}$ \\
\hline Escherichia coli & EC27 & Surgical wound & $\begin{array}{c}\text { Ast, Ax, Amp, Ami, Amox, Ca, Cfc, Cf, Caz, Cip, } \\
\text { Clo, Imi, Can, Szt, Tet, Tob }\end{array}$ \\
\hline
\end{tabular}

Resistance Profile: Ami = amikacin; Sam = ampicillin-sulbactam; Cip = ciprofloxacin; Lev = levofloxacin; $\mathrm{Cpm}=$ cefepime; $\mathrm{Ctz}=$ ceftazidime; $\mathrm{Pol}=$ polymyxin; $\mathrm{Imi}=$ imipenem; $\mathrm{Mer}=$ meropenem; $\mathrm{Ptz}=$ piperacillin; Tig = tigecycline; Ast = aztreonan; $\mathrm{Ax}=$ Amoxicillin; $\mathrm{Amp}=$ ampicillin; Amox $=$ amoxilin, $\mathrm{Ca}=$ cefadroxil; $\mathrm{Cf}=$ cefaclor $; \mathrm{Cf}=$ cephalothin $\mathrm{Caz}=$ ceftazinidime; $\mathrm{Clo}=$ chloramphenicol $; \mathrm{Can}=$ kanamycin; $\mathrm{Szt}=$ sulfametrim; Tet = tetracycline; Tob = tobramycin; Oxa = oxacillin; Gen = gentamicin; Neo = neomycin; Para = paramomycin; But $=$ butyrosine; Sis = sisomycin; Net $=$ netilmicin. The microorganisms used in this research were acquired from the Laboratory of Mycology of the Federal University of Paraiba-UFPB and kindly provided by the Regional University of Cariri-URCA.

\subsection{Statistical Analysis}

The results from the assays were expressed as the geometric mean of triplicates. The data were analyzed using an ANOVA followed by Bonferroni's post-hoc test using the GraphPad Prism 6.0 software. Differences with a $p<0.05$ were considered significant.

\subsection{Data Statement}

The quantitative data used to support the findings of this study are included in the article.

\section{Conclusions}

In conclusion, the hexanic Zea mays L. silk extract did not present a clinically significant antibacterial effect against standard and multiresistant bacteria. However, the extract selectively modulated the action of aminoglycoside antibiotics against multiresistant bacteria, indicating that its components present antibiotic-modulating effects. 
Therefore, further research is required to isolate the extract's bioactive compounds and identify which constituents promote synergism or antagonism in association with antibiotics. Thus, chemical components of the Zea mays silk extract may be used in the development of novel drugs useful for the treatment of infections caused by microorganisms resistant to conventional antibiotics.

Author Contributions: Formal analysis, J.J.d.S.A.; Investigation, A.B.L.d.C., C.A.C., C.L.A.d.F. and P.L.W.d.S.N.; Methodology, V.M.d.S.L. and D.F.M.; Supervision, H.D.M.C.; Writing—original draft, E.F.F.M.

Funding: This research did not receive any specific funding.

Conflicts of Interest: The authors declare no conflict of interest.

\section{References}

1. Badke, M.R.; Budó, M.d.D.; da Silva, F.M.; Resse, L.B. Plantas medicinais: O saber sustentado na prática do cotidiano popular. Esc Anna Nery 2011, 15. [CrossRef]

2. Pinto, E.P.P.; Amorozo, M.C.M.; Furlan, A. Conhecimento popular sobre plantas medicinais em comunidades rurais de mata atlântica-Itacaré, BA, Brasil. Acta Bot. Bras. 2006, 20. [CrossRef]

3. Aldrich, S.R.; Scott, W.O.; Hoeft, R.G. Modern Corn Production, 2nd ed.; A \& L Publication: Champaign, IL, USA, 1982.

4. Pinheiro, A.C.S.; Pais, A.A.; Tardivo, A.C.B.; Alves, M.J.Q.F. Efeito do extrato aquoso de cabelo de milho (Zea mays L.) sobre a excreção renal de água e eletrólitos e pressão arterial em ratos Wistar anestesiados. Rev. Bras. Plantas Med. 2011, 13, 375-381. [CrossRef]

5. Kwiatkowski, A.; Clemente, E. Características do milho doce (Zea mays L.) para industrialização. Rev. Bras. de Tecnol. Agroindustrial 2007, 1. [CrossRef]

6. Paiva, E.; Vasconcelos, M.J.V.; Parentoni, S.N.; Gama, E.E.G.; Magnavaca, R. Seleção de progênies de milho doce de alto valor nutritivo com auxílio de técnicas eletroforéticas. Pesq. Agropec. Bras. 1992, 27, 1213-1218.

7. Barbosa, A.S.; Sousa, E.G.; Silva, M.A.; Oliveira, H.S.M.C.; Medeiros, M.B. Plantas medicinais: Aspecto do uso de fitoterápicos na melhoria da qualidade de vida humana. In X Encontro de iniciação a docencia; UFPB-PRG: João Pessoa, Brazil, 2007.

8. Leite, D.C.S.; Ferreira, F.E.; Souza, D.M.S.; Santos, D.I.; Lima, W.L.; Mangueira, C.E.A.; Aguiar, J.J.S. Perfil químico, antibacteriano, modulador a aminoglicosídeos e citotoxicidadedo do extrato aquoso do estigma de Zea Mays. In Proceedings of the IV Congresso Caririense de Biomedicina, Juazeiro do Norte, Brazil. 2017. ISBN 978-85-65221-24-5. Available online: https:/ /leaosampaio.edu.br/downloads/copex/anais/Anais_ do_IV_Congresso_de_Biomedicina.pdf (accessed on 16 December 2018).

9. Tortora, G.J.; Funke, B.R.; Case, C.L. Crescimento Microbiano, Microbiologia, 10th ed.; Artmed: Porto Alegre, Brazil, 2012.

10. Kumar, V.; Abbas, A.; Aster, J.C. Robbins \& Cotran Patologia-Bases Patológicas das Doenças; Elsevier: São Paulo, Brasil, 2015.

11. Silveira, G.P.; Nome, F.; Sá, J.C.G.M.M.; Terenzi, H. Estratégias utilizadas no combate a resistência bacteriana. Química Nova 2006, 29, 844-855. [CrossRef]

12. Kaur, D.; Divneet, K.; Anuja, C.; Poonam, A. Corn silk: A review on botanical and harmacological considerations. Eur. J. Biomed. Pharm. Sci. 2015, 2, 554-572.

13. Flambó, D.F.A.L.P. Atividades Biológicas dos Flavonoides: Atividade Antimicrobiana. Dissertação de tese de (Mestrado Ciências Farmacêuticas), Universidade Fernando Pessoa Faculdade de Ciências da Saúde, Porto, Portugal, 2013.

14. Xiao, Z.Y.; Shiu, W.K.P.; Zeng, Y.H.; Mu, Q.; Gibbons, S. A naturally occurring inhibitory agent from Hypericum sampsonii with activity against multidrug-resistant staphylococcus aureus. Pharm. Biol. 2008, 46, 250-253. [CrossRef]

15. Santos, S.C.; Mello, J.C.P. Taninos. In Farmacognosia: Da planta ao medicamento; Simões, C.M.O., Schenkel, E.P., Gosmann, G., Mello, J.C.P., Mentz, L.A., Petrovick, P.R., Eds.; UFRGS: Porto Alegre, Brazil, 1999; pp. 614-656.

16. Nishizawa, K.; Nakata, I.; Kishida, A.; Ayer, W.A.; Browne, L.M. Some biologically active tannins of Nuphar variegatum. Phytochemistry 1990, 29, 2491-2494. [CrossRef]

17. Monteiro, J.M.; Albuquerque, U.P.; Araujo, E.d.L.; Amorim, E.L.C.d. Taninos: Uma abordagem da química à ecologia. Química Nova 2005, 28, 892-896. [CrossRef] 
18. Domingo, D.; LOPEZ-BREA, M. Plantas con acción antimicrobiana. Rev. Española de Quimioterapia 2003, 16, 385-393. [PubMed]

19. Alves, E.F.; Santos, B.S.; Matias, E.F.F. Avaliação da atividade antibacteriana e modulatória da fração hexânica do extrato hexânico de Cordia verbenacea DC. Rev. Interfaces Saúde, Humanas e Tecnol. 2014, 2. [CrossRef]

20. Dixon, R.A.; Dey, P.M.; Lamb, C.J. Phytoalexins: Enzymology and molecular biology. Adv. Enzymol. Relat. Areas Mol. Biol. 1983, 55, 1-69. [PubMed]

21. Tsuchiya, H.; Sato, M.; Miyazaki, T.; Fujiwara, S.; Tanigaki, S.; Ohyama, M.; Tanaka, T.; Jinuma, M. Comparative study on the antibacterial Activity of phytochemical flavanones against methicillin-resistant Staphylococcus aureus. J. Ethnopharmacol. 1996, 50, 27-34. [CrossRef]

22. Behling, H.; Pillar, V.D.; Orlóci, L.; Bauermann, S.G. Late Quaternary Araucaria forest, grassland (Campos), fire and climate dynamics, studied by high-resolution pollen, charcoal and multivariate analysis of the Cambará. do Sul core in southern Brazil. Palaeogeogr. Palaeoclimatol. Palaeoecol. 2004, 203, 277-297. [CrossRef]

23. Coutinho, H.D.M.; Costa, J.G.M.; Siqueira-Júnior, J.P.; Lima, E.O. In vitro anti-staphylococcal activity of Hyptis martiusii Benth against methicillin-resistant Staphylococcus aureus: MRSA strains. Rev. Bras. de Farmacognosia 2008, 18. [CrossRef]

24. Matos, F.J.d.A. Plantas Medicinais—Guia de seleção e emprego de plantas usadas em fitoterapia no nordeste do Brasil, 2nd ed.; Imprensa Universitária UFC: Fortaleza, Brazil, 2000.

25. CLSI. (janeiro de 2005). ANVISA, M7-A6. (Agencia Nacional de Vigilância Sanitária) Acesso em 07 de Fevereiro de 2017, disponível em Site da Agencia Nacional de Vigilância Sanitária. Available online: http: / /www.anvisa.gov.br/servicosaude/manuais/clsi/clsi_opasm7_a6.pdf (accessed on 14 November 2018).

26. Javadpour, M.M.; Juban, M.M.; Lo, W.C.; Bishop, S.M.; Alberty, J.B.; Cowell, S.M.; Becker, C.L.; McLaughlin, M.L. De novo antimicrobial peptides with low mammalian cell toxicity. J. Med. Chem. 1996, 39, 3107-3113. [CrossRef] [PubMed]

27. NCCLS-National Comittee For Clinical Laboratory Standards. Methods for Dilution Antimicrobial Susceptibility Tests for Bacteria That Grow Aerobically, 5th ed.; NCCLS approved standard M7-A5: Villanova, PA, USA, 2000; Volume 20.

28. Figueredo, F.G.; Ferreira, E.O.; Lucena, B.F.; Torres, C.M.; Lucetti, D.L.; Lucetti, E.C.; Silva, J.M.; Santos, F.A.; Medeiros, C.R.; Oliveira, G.M.; et al. Modulation of the Antibiotic Activity by Extracts from Amburana cearensis A. C. Smith and Anadenanthera macrocarpa (Benth.) Brenan. Biomed Res. Int. 2013, 2013. [CrossRef] [PubMed]

29. Hi Leite, L.; Tintino, S.R.; Figueredo, F.G.; Oliveira, C.D.d.; de Oliveira, L.; Siebra, A.L.d.; Sampaio, R.d.; Boligon, A.A.; Souza, D.O.; Athayde, M.L.; et al. Composição química e estudo da atividade antibacteriana de Bowdichia virgilioides Kunth (Sucupira)-Fabaceae-Papilonoidae. Boletín Latinoamericano y del Caribe de Plantas Medicinales y Aromáticas 2014, 13, 477-487.

30. Salvat, A.; Antonnacci, L.; Fortunato, R.H.; Suarez, E.Y.; Godoy, H.M. Screening of some plants from Northern Argentina for their antimicrobial activity. Lett. Appl. Microbiol. 2001, 32, 293-297. [CrossRef] 